ment of a nurse in the almshouses in their respective localities as an experiment, to prove that the reform is needed. The cooperation of the Nurses' State Association would be in appointing the nurses and supervising their work.

The discussion that followed the paper resulted in the appointment of a committee to confer with the Michigan State Federation of Women's Clubs relative to inaugurating the movement.

This is the first time that such an affiliation with a nurse's association has been recommended. There are in the recommendation suggestions of possibilities of great service to the sick poor, and of advantage to the nurses, who by cultivating that neglected field "would experience a call upon their utmost resources of ability, training and character "

There is, furthermore, presented in the suggestion an opportunity for different hospitals of the state to affiliate with the almshouses and furnish them with pupil nurses to do their nursing under a trained graduate supervisor.

Many valuable lessons in the education of the pupil nurse would be acquired through such an arrangement. Humane and scientific care of the homeless. friendless sick, most of whom are aged and infirm, would add to a nurse's education experience, which makes for success in private nursing or in any other line of her professional work.

Where else could she better learn the lessons of reverence for old age and patience with its vagaries and caprices; consideration for sensitive feelings; tolerance and pity for ignorance and misfortune, and the sympathy which prompts the ameliorating of the sad conditions of human life as much as lies in one's power?

We have faith to believe that the neglected field will become a cultivated field; and we heartily endorse the action of the Michigan State Nurses' Association in the initiative they have taken to aid in bringing about the reform.

\title{
THE NEW YORK SYMPOSIUM ON NURSING
}

WE publish in this issue a letter from a New York nurse who attended the symposium on nursing held at the Academy of Medicine in New York on the evening of March 29.

The nurses who responded to the public invitation to attend this symposiun found themselves in a somewhat unique situation.

A company of medical gentlemen occupied the evening in reading papers and making addresses, criticising,-we might almost say 
abusing,--training-schools and nurses, nurses' organizations and the Nurse Board of Examiners, in a wholesale sarcastic manner, but not offering to the nurses in the audience an opportunity to say a word in their own defense.

The trend of opinion among these gentlemen seems to have been that nurses are getting to he too independent of the medical profession: that schools for nurses are overtraining their pupils, and that the nursing organizations are in the nature of trusts.

As is often the case, many of the statements made showed lack of knowledge of the true situation; ignorance of the motives upon which nursing organizations have been formed, a misunderstanding of the lines upon which the Nurse Examiners are working, and a total lack of appreciation of what the teaching body are hoping to attain through higher education.

One of the first lessons instilled into the nurse is that of loyalty to the phrsician; perhaps it has been a mistake that because of this loyalty nurses have not published broadly the motives for some of the steps which have been taken by them in their efforts for higher education.

For instance, the establishment of the course at Teachers College by the American Society of Superintendents of Training-Schools, which is maintained by personal contributions from the great nursing body of the country, and which has for its object the training of nurse teachers to teach nursing to nurses, is in itself a criticism, or to put it more strongly, a condemnation of the results of the teaching of nurses by physicians during the past thirty years, these results being quite as unsatisfactory to the nurses themselves as they seem to have been to the medical gentlemen who took part in the symposium.

No one more than nurses themselves appreciates the unsatisfactory chaotic conditions existing in the nursing field to-day, the result largely of medical dominance and medical teaching of nurses.

The whole broad aim of the nursing movement is to better these conditions, in coöperation with the great medical body so far as may be, in independence of that body if must be, the ultimate aim being a better educated class of women, a more useful and practical type of nurse, with better nursing service in the homes of all the people, and a more intelligent service to the physician, but with this difference, the nurse of the future will work with the physician as his assistant and intelligent co-worker and not as his-servant. It is the social uplift coming through organization and state registration that we think these gentlemen object to. 
At the present time matters are in a transition state; the nurses must be given time to do for themselves what the medical body has done for itself (once doctors were barbers). This unsatisfactory state will never be corrected until the responsibility for all the faults of character and education are thrown back upon the members of the great nursing body as a whole. The doctors have dominated training-schools for thirty years and the result is bad. The nurses should at least have a "try" at the management of their own affairs. They can't very well produce worse results and there is the chance that with so much at stake they may do a little better.

Dr. Gilman Thompson, who seemed to have the greatest number of grievances, is an old-time complainer, so we are told, in nursing affairs. Dr. Ludlam, superintendent of the New York Hospital, at one time was the head of the training-school but it was deemed wise by the management to relieve him of that responsibility. Dr. Gerster, of the staff of Mt. Sinai, was the least critical, and although of the opinion that nurses should be taught very little, still he was honest enough to say that the medical profession was largely responsible for the present tendency to overtrain. Dr. Abbe thought he could teach a nurse in a week all that she needed to know. He has the ten-weeks schools to draw from.

\section{CRITICISMS OF THE BOARD OF NURSE EXAMINERS}

Dr. Thompson afforded himself great pleasure and satisfaction in criticising the questions prepared by the New York Board of Nurse Examiners for the first full examination, held on the last day of January, and was specially incensed that the examiners should have presented what he considers to be medical questions.

He entirely lost sight of the fact that one half of this examination was practical; that each student presenting herself for examination appeared before one of the examiners and was required to demonstrate her ability to perform such practical details as the making and changing of a bed, giving a bath, making a poultice, preparing the syringe and solution for a hypodermic injection; preparing the hands for and applying a surgical dressing, etc. And he also did not know that the examiners found themselves very much embarrassed when the time came to prepare for the first full examination by the fact that there was no means of judging of what the nurses of the state had been taught during the past three years.

As a guide the secretary of the board was instructed to write to all the registered schools in the state, eighty-five or more, for copies 
of their last year's written examination questions. A most cordial response was received from all but a few, with a wonderful conglomeration of questions, taken as a whole. This budget was passed along from one eximiner to another and with the exception of bacteriology each one selected ten of the very simplest of the questions found therein upon her subjects, many of the questions having to be greatly modified in order to be used in making up a paper of minimum requirements.

If these questions are medical questions, they were of the doctors' own propounding in the different schools.

Critıcisms have also reached the board that the superintendents of some of the large hospitals in New York City are saying that the questions were too hard; that the superintendents themselves could not answer them, much less the pupils.

It is to the credit of the instruction given in the small two-yearcourse schools of the State that five out of the seven two-year graduates who came up for this examination passed at a percentage of 75 or more.

We think perhaps a short cut to improve the training-schools would be to require the superintendents to pass the Regents' examinations: and if there are women holding hospital positions who cannot give the table of weights and measures, and who would give the cavities of the body and their contents as being "The eyes, the ears, the nose, the mouth," and the definition of bacteria as "a growing of germs," the quicker such women are thrown out of their positions the better for the progress of nursing.

We think possibly the time has come for the nurses to hold a public symposium on doctors and tell of the things that doctors do that are not to the advantage of the hospitals with which they are connected or the patients for whom they care.

It might be well to show up the type of man who collects fees from the public ward patients during his term of service; of the man who lets his patient die on the table while he spends two hours in finding a perfectly normal appendix; or the one who lets a patient die "as the result of shock" with a ligature tied securely around a ureter; of the sponges found in the abdomen after the patient has died of peritonitis; of house officers too drunk to write their orders at night; of lecturers to the nurses in training who only come on rainy days when the weather is not propitious for golf or bird-hunting; of solutions ordered in ounces instead of drams which would have been given and caused a death but for the intelligence of the "over-trained nurse," 
etc. An endless chain of incidents could be presented that would be intensely interesting to the public and possibly to the medical profession, as showing the extent and character of the nurse's loyalty.

Such a symposium as the one held in New York is of great value to the nursing profession as showing the lines along which reforms must be most vigorously directed, and also because such attacks bind nurses more closely together and teach them how to defend themselves.

Fortunately these gentlemen do not represent the entire medical profession; they are men with a grievance who have been obliged to "hire a hall" in order to make themselves heard.

But, seriously, the opposition to higher education for nurses is but a part of the old worn-out opposition to higher education for women as a whole. We have only to demonstrate that it makes better nurses, and go steadily on.

\section{PROGRESS OF STATE REGISTRATION}

\section{MICHIGA.N}

It was our very great privilege to be a guest at the meeting of the Michigan State Nurses' Association held in Ann Arbor on April 4, 5 and 6 , when the bill for state registration which passed the Senate last year, but was defeated in the House, was again brought forward for discussion. This bill as orginally drawn contained all of the essential points and was an exceedingly good bill. There will be some unimportant changes made in it before it is presented next year.

The reason for its defeat last year was the old political excuse that the state would not establish any more commissions, but the nurses felt that the fact that the bill was introduced so late in the session had much to do with its defeat. A well-organized campaign is to be commenced early and the bill will be presented as soon as the legislature opens in 1907.

There are an exceedingly able group of leaders in Michigan and we have never attended a more splendidly arranged meeting. The president, Miss Sly, and the chairman of the committee of arrangements and Miss Haarer are to be especially commended for the excellence of their work. A brief report is found on another page. The association will publish a full report of its proceedings, with the papers read and the discussions. We only regret that we are unable to increase the Journal pages sufficiently to give the full proceedings of all 